\title{
Influence of Water quality on the biodiversity of phytoplankton in Dhamra River Estuary of Odisha Coast, Bay of Bengal
}

\author{
PALLEYI, S; KAR, R N; *PANDA, C R
}

Institute of Minerals \& Materials Technology, Bhubaneswar-751013, India

*Corresponding author: drpanda_cr@yahoo.com

\begin{abstract}
Dhamra estuarine ecosystem is a hotspot of rich biological diversity which supports a patch of mangrove along with unique flora and fauna. In this study, the diversity of phytoplankton population and other factors that control their growth and biodiversity were investigated. The samples were collected monthly from Dhamra estuary of Bay of Bengal at 6 different stations (grouped under three regions) from March -2008 to February -2009. A total of 41 genera of phytoplankton species belonging to 4 classes of algae were identified. The maximum value of $9.3 \times 10^{4}$ cells $\mathrm{l}^{-1}$ was recorded in post monsoon season. Phytoplankton of Bacillariophyceae, appearing throughout the year, and represent majority of population (75-94\%) at all the sampling stations, followed by Dinophyceae (3-14\%), Cyanophyceae (3-8\%) and Chlorophyceae (0-4\%) classes. The Shannonweavers diversity index $(\mathrm{H})$ remains between 0.22 and 2.49. Based on the correlation coefficient data, phytoplankton shows positive relationship with DO, salinity, nutrients and negative relationship with temperature and turbidity. Present study shows that the occurrence and diversity of these primary producers do not subscribe to a single dimensional phenomenon of a single factor, rather than, a consequence of a series of supported factors which will help to maintain and balance such type of fragile ecosystem. @JASEM
\end{abstract}

Estuaries are characterized by the gradient of salinity in a semi enclosed coastal system, flourishing a group of organisms uniquely capable of using the salinity gradient to a competitive advantage. Phytoplanktons represent the base of pelagic food webs in estuarine ecosystem and play a major role in the global cycling of carbon, nitrogen, phosphorus and other elements and the regulation of earth's climate. The biomass distribution and species composition of phytoplankton have important effects on carbon fixation rates and on transfer of energy in food webs. Studies of the abundance, distribution and composition of phytoplankton communities are, therefore, a fundamental contribution to our understanding of the structure and function of estuarine ecosystems. Phytoplankton communities are multispecies communities, which are highly multifaceted in terms of their diversity and dynamics. Successional shifts in phytoplankton community structure are mainly due to changes in environmental variables such as nutrients and other physicochemical variables which influence the distribution and abundance of plankton communities in estuaries (Cleorn, 1987; Ferreira et al., 2005; Madhu et al., 2007).

Estuarine regions are important sinks for several elements. In this study we tried to identify and asses the trend of phytoplankton species diversity at Dhamra Estuarine region with the water physico chemical parameters. Dhamra river is the union of river Brahmani and Baitarani, the two largest rivers of Orissa, situated at the Bhadrakh district, just north of the boundary of Bhitarkanika wild life sanctuary, famous for its estuarine crocodiles and approximately $10 \mathrm{~km}$ from the Gahirmatha marine sanctuary, which is the world's most important nesting beach for Olive Ridley sea turtles on the Orissa coast of Bay of Bengal.

Although, a number of studies have been carried out on the ecological conditions of estuarine region, as Bay of Bengal is considered as a low productive zone (Madhupratap, et al., 2003), very limited work has been done in the east coast of Orissa. Moreover, not as much of information on phytoplankton species composition and diversity is available in this particular estuarine region.

\section{MATERIALS AND METHODS}

Sampling of surface water was carried out throughout the year (March-2008 to February-2009) on a monthly basis at Dhamra River Estuarine region. A total of 6 stations, where station- 1 and 2 covers the lower estuarine region (marine region, depth-63 ft), station-3 and station- 4 covers the river mouth region having depth of $27 \mathrm{ft}$ and $26 \mathrm{ft}$, respectively and station-5 (26ft) and station-6 (26ft) were the riverine region or fluvial region dominated by freshwater but subjected to tidal action.

Water samples for the measurement of salinity, turbidity and nutrient parameters were collected in Polypropylene bottles and for DO and BOD measurement, water samples were collected in DO bottles and analysed by Winkler method. The temperature and salinity was measured in situ using sensor based Multi WTW 340i/set. Salinity was again cross-checked by silver nitrate titration (Oxner, 1920). Turbidity was measured by Nephlometric method using HACH 2100P Turbidimeter. Basic nutrient parameters (nitrite, nitrate, ammonia and 
phosphate) were measured according to standard methods (Grasshoff, 1999). For quantitative and qualitative analyses of phytoplankton (Verlencar, 2004), a Sedgwick-Rafter plankton counting chamber was used and samples were examined microscopically by trinocular Nikon 90i Eclipse automated microscope. All 1,000 squares on the chamber were screened (Gilbert, 1942). Empty frustules were not included in the total counts. Phytoplankton cell identifications were based on standard taxonomic keys (Verlencar, 2004; Botes, 2003). The results are expressed as numbers of cells $\mathrm{L}^{-1}$ and phytoplankton diversity was calculated using Shannon's diversity index. (Shannon and Weaver, 1949)

$\mathrm{H}=-\sum$ pi ln pi

Where $\mathrm{H}$ - is the diversity index; $\mathrm{ln}$ - is the natural logarithm; i - is an index number for each species present in a sample; pi - is the number of individuals within a species (ni) divided by the total number of individuals $(\mathrm{N})$ present in the entire sample.

\section{RESULT AND DISCUSSION}

Phytoplankton abundance and species composition showed both spatial and seasonal variation. The dominant species recorded at different sampling stations belonged to the genera Coscinodiscus, Skeletonema, Nitzschia, Navicula, Thallasiothrix, Triceratium, Biddulphia, Ceratium, Rhizosolenia, Thallasionema, Bacillaria, Chaetocerous, Melosira, Trichodesmium, Podosira, Pleurosigma. There was succession of different species recorded during different sampling seasons at different sampling points. The numbers of phytoplankton genus under these classes are identified as Bacillariophyceae 31 genus and several species, 2 genus of Chlorophyceae, 6 genus of Dinophyceae and 2 genus of Cyanophyceae. The percentage occurrence of different phytoplankton groups with respect to total phytoplankton taxa at six different stations of Dhamra estuary throughout the year has been given in Figure-I. The Shannon's diversity indexes were also graphically presented in Figure-II. The correlation coefficient values of different physicochemical and biological data of Dhamra estuarine water samples throughout the year are presented in Table 1. With growth and turnover rates of less than a day, phytoplankton are very susceptible to changes in the environment, and large variations in phytoplankton species composition are often a reflection of significant alteration in ambient conditions within an ecosystem. Basically, Diatom (class- Bacillariophyceae), Dinoflagellates (classDinophyceae), Cocolithophores and Silicoflagellates (class- Chrysophyceae) and blue-green algae (classCyanophyceae) are the principal phytoplankton taxa in the ocean. In Dhamra estuarine water sample, phytoplankton belonging to class Bacillariophyceae dominated over other classes of phytoplanktons at all the 6 stations in the whole year (March-08 to Feb09). After Bacillariophyceae, some genus of Dinophyceae, few of Cyanophyceae and occasionally Chlorophyceae genus were observed (Fig 2).

Plankton communities in the estuary can be served as an indicator for the change in ecosystems under the pollution stress. In ecology, a diversity index is a statistics, which is applied to measure the species biodiversity in an ecosystem. A stressed environment typically has a lower number of species with one or two species (those adapted to the stress) having many more individuals than the other species ( $\mathrm{Gao}$ and Song, 2005). As our study area was identified as a low productive zone (Madhupratap et al., 2003), the diversity index remained between 0.22 and 2.49 throughout the year at all the sampling stations (Fig 2). During the post monsoon season, as a result of fresh water flushing and changes in salinity, the estuarine region experiences the most dramatic change in phytoplankton species composition, as is evident from the diversity index data (Fig 2). The highest phytoplankton population density reached upto $9.3 \times 10^{4}$ cells $1^{-1}$ at river mouth region during the month of December-2008 (in the post monsoon season). The total phytoplankton community during this proliferation was composed mainly of diatoms and dominated by a single diatom species Pleurosigma angulatum. Abiotic features in estuaries vary depending upon the degree of protection from water motion (waves, tidal currents), the quality of fresh water input and circulation patterns including residence time of the water, depth and salinity gradient. Further abiotic factors change both temporally and spatially, so that a wide variety of habitats exist in estuaries. Diversity and abundance of phytoplankton are related to the physico chemical parameters in general and more particularly to temperature, DO, BOD, salinity and nutrient availability. The correlation coefficient values between physico chemical parameters and the algal population of three distinct regions have been presented in Table 1 . 
Table 1: Correlation coefficient values among certain physico-chemical parameters at three regions of Dhamara estuary Marine Region: Phy = Phytoplankton; sal = salinity; Tur = Turbidity

\begin{tabular}{|c|c|c|c|c|c|c|c|c|c|c|}
\hline & Temp & Tur. & $D O$ & $B O D$ & Sal & $\mathrm{NO}_{2}^{-}$ & $\mathrm{NO}_{3}^{-}$ & $\mathrm{NH}_{3}^{-}$ & $\mathrm{PO}_{4}{ }^{3-}$ & Phy \\
\hline Temp & 1 & & & & & & & & & \\
\hline Tur & -0.19 & 1 & & & & & & & & \\
\hline$D O$ & -0.55 & 0.08 & 1 & & & & & & & \\
\hline$B O D$ & -0.22 & 0.23 & 0.50 & 1 & & & & & & \\
\hline Sal & 0.30 & 0.08 & -0.03 & 0.30 & 1 & & & & & \\
\hline $\mathrm{NO}_{2}^{-}$ & 0.13 & -0.09 & 0.22 & -0.07 & -0.36 & 1 & & & & \\
\hline $\mathrm{NO}_{3}^{-}$ & 0.56 & 0.00 & -0.32 & 0.06 & 0.44 & 0.10 & 1 & & & \\
\hline $\mathrm{NH}_{3}^{-}$ & 0.56 & -0.11 & -0.38 & 0.15 & 0.43 & -0.17 & 0.65 & 1 & & \\
\hline $\mathrm{PO}_{4}^{3-}$ & 0.36 & 0.37 & 0.25 & 0.31 & 0.38 & 0.09 & 0.28 & 0.14 & 1 & \\
\hline Phy & -0.32 & -0.27 & 0.70 & 0.37 & 0.02 & 0.23 & 0.27 & 0.39 & 0.23 & 1 \\
\hline
\end{tabular}

River Mouth region: Phy = Phytoplankton; sal = salinity; Tur = Turbidity

\begin{tabular}{|c|c|c|c|c|c|c|c|c|c|c|}
\hline & Temp & Tur. & $D O$ & $B O D$ & Sal & $\mathrm{NO}_{2}^{-}$ & $\mathrm{NO}_{3}^{-}$ & $\mathrm{NH}_{3}^{-}$ & $\mathrm{PO}_{4}{ }^{3-}$ & Phy \\
\hline Temp & 1 & & & & & & & & & \\
\hline Tur & -0.32 & 1 & & & & & & & & \\
\hline$D O$ & -0.64 & 0.34 & 1 & & & & & & & \\
\hline$B O D$ & -0.36 & 0.64 & 0.50 & 1 & & & & & & \\
\hline Sal & 0.19 & 0.22 & 0.24 & 0.26 & 1 & & & & & \\
\hline $\mathrm{NO}_{2}^{-}$ & 0.25 & -0.20 & -0.14 & -0.44 & -0.29 & 1 & & & & \\
\hline $\mathrm{NO}_{3}^{-}$ & -0.05 & 0.11 & 0.19 & 0.21 & 0.24 & -0.18 & 1 & & & \\
\hline $\mathrm{NH}_{3}^{-}$ & 0.60 & -0.04 & -0.15 & 0.12 & 0.53 & -0.09 & 0.15 & 1 & & \\
\hline $\mathrm{PO}_{4}^{3-}$ & -0.51 & 0.24 & 0.37 & 0.40 & -0.29 & -0.19 & 0.05 & -0.37 & 1 & \\
\hline Phy & -0.60 & -0.01 & 0.50 & 0.04 & 0.24 & 0.23 & 0.16 & 0.18 & 0.17 & 1 \\
\hline
\end{tabular}

\begin{tabular}{|c|c|c|c|c|c|c|c|c|c|c|}
\hline \multicolumn{11}{|c|}{ Fluvial region: Phy $=$ Phytoplankton; sal = salinity; Tur $=$ Turbidity } \\
\hline & Temp & Tur. & $\mathrm{DO}$ & $B O D$ & Sal & $\mathrm{NO}_{2}^{-}$ & $\mathrm{NO}_{3}^{-}$ & $\mathrm{NH}_{3}^{-}$ & $\mathrm{PO}_{4}^{3-}$ & Phy \\
\hline Temp & 1 & & & & & & & & & \\
\hline Tur & -0.25 & 1 & & & & & & & & \\
\hline DO & -0.46 & -0.11 & 1 & & & & & & & \\
\hline$B O D$ & -0.36 & 0.33 & 0.45 & 1 & & & & & & \\
\hline Sal & 0.19 & 0.19 & 0.14 & 0.31 & 1 & & & & & \\
\hline $\mathrm{NO}_{2}^{-}$ & 0.17 & 0.39 & -0.06 & 0.10 & 0.04 & 1 & & & & \\
\hline $\mathrm{NO}_{3}^{-}$ & -0.32 & 0.54 & 0.19 & 0.41 & 0.18 & 0.24 & 1 & & & \\
\hline $\mathrm{NH}_{3}^{-}$ & 0.12 & 0.70 & -0.24 & 0.32 & 0.41 & 0.26 & 0.31 & 1 & & \\
\hline $\mathrm{PO}_{4}{ }^{3-}$ & -0.43 & 0.02 & -0.06 & 0.30 & -0.16 & -0.35 & 0.11 & -0.30 & 1 & \\
\hline Phy & -0.02 & -0.32 & 0.55 & 0.28 & 0.49 & 0.16 & 0.00 & 0.24 & 0.00 & 1 \\
\hline
\end{tabular}

PALLEYI, S; KAR, R N; PANDA, C R 

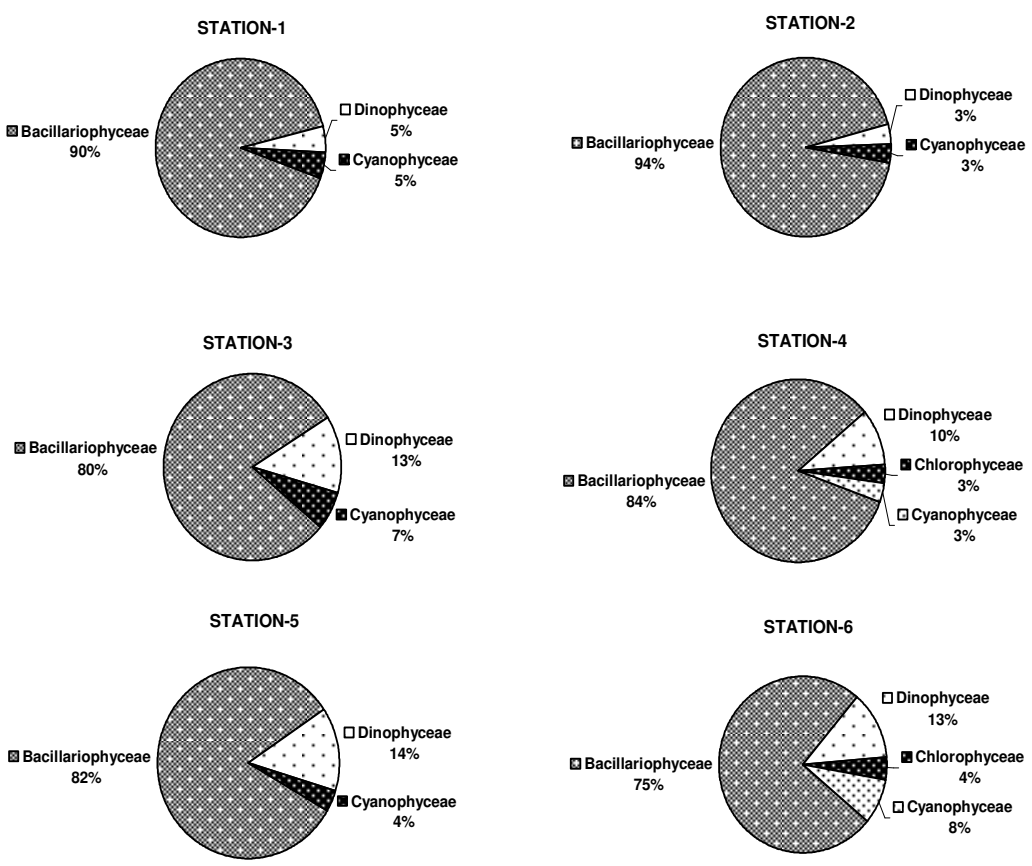

Fig 1: Percentage composition of different phytoplankton classes at sampling station 1 to 6 of Dhamra Estuary

As a matter of fact, positive correlationship was observed between dissolved oxygen and phytoplanktons. Salinity is measured because of its influence on the distribution and diversity of many living marine species. The rate of cell division of these microfloras, as well as their occurrence, distribution and productivity is influenced by salinity and in this study phytoplanktons have shown a positive correlation with salinity value at all the sampling stations because estuarine regions are subjected to considerable fluctuations and these micro flora were well adapted to such vicissitude environment (Kinne, 1972; Lionard et al., 2005). Phytoplanktons need a wide variety of chemical elements but the two critical ones are nitrogen and phosphorous (Dawes, 1981). And we found that phytoplanktons show positive correlation with phosphate and inorganic nitrogenous nutrient parameters but the relationship was not very significant. This may be due to lower concentration or may be rapid recycling of these nutrients. Similar observations were made by Steinhart et al. (2002) and Hergenrader (1980). Temperature and turbidity manifested negative relationship with phytoplanktons. Early workers also reported the same relationship of phytoplanktons with temperature and turbidity (Dawes, 1981).

The overall findings of this study revealed that climatic conditions as well as ionic chemistry of the ecosystem influence the species composition and their relative abundance of phytoplankton in the Dhamra estuarine region. This study of phytoplankton biodiversity at Dhamra estuary of Orissa coast, Bay of Bengal revealed that the population peak was mainly contributed by a single species proliferation, which led to low diversity index. But still it does not impart any harsh effect to the biotic community, because the major organism was not listed under toxic phytoplanktons. Although the bloom was not creating any stressful condition, still it could have been better if the peak population was also associated with highest diversity index. A perfect relationship between specific environment factor and change in phytoplankton community structure was yet to be established. However, this study provides clear information regarding occurrence of an intermediate level of phytoplankton population and minimum diversity during massive blooming period in this particular estuary.

Acknowledgements: The authors are thankful to the Director, IMMT, Bhubaneswar for his kind permission to publish the work. Thanks are also due to the Dhamra Port Co. Ltd., for providing necessary funding to carry out the work. 


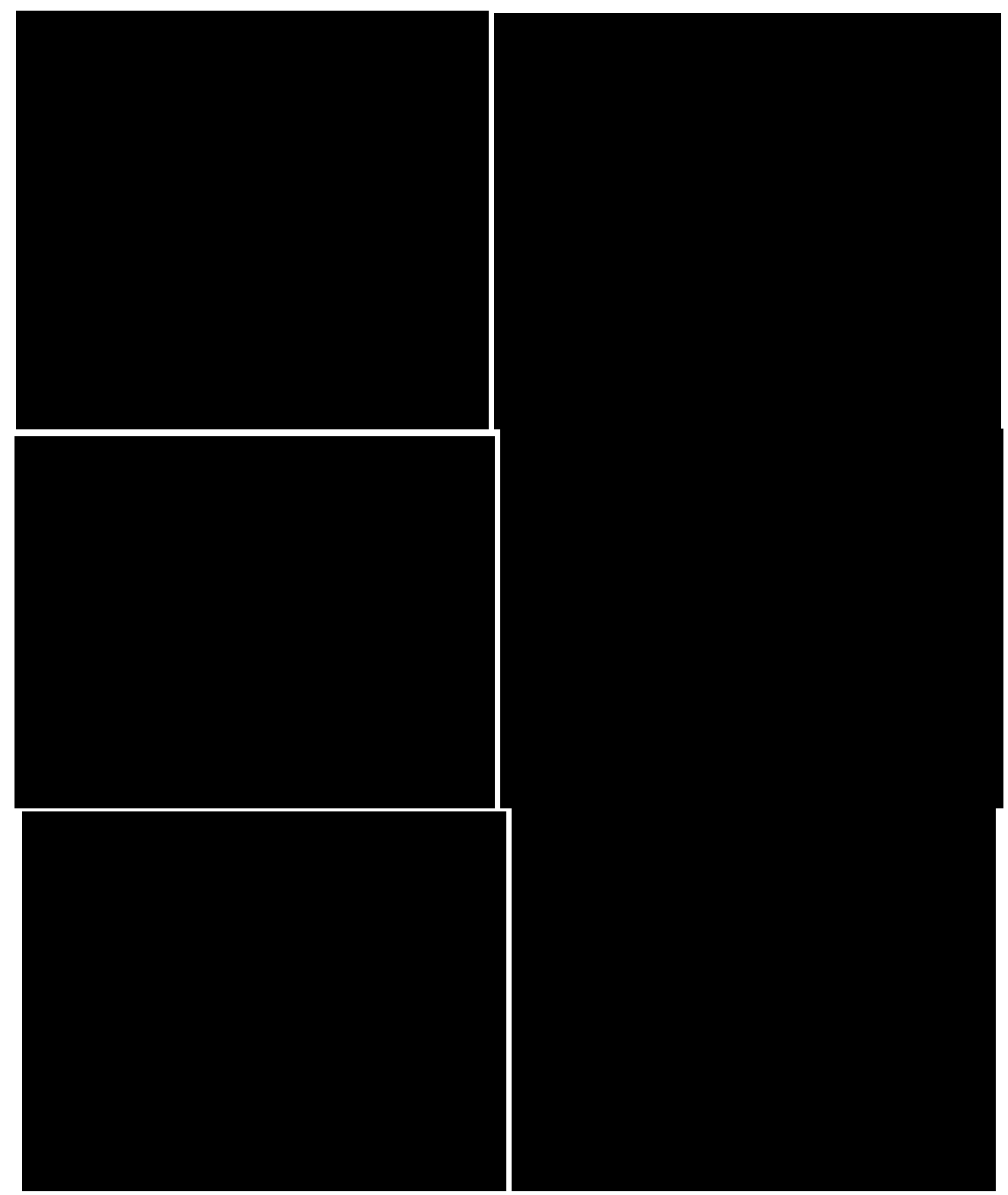

Fig 2: Variation in Phytoplankton species diversity index of six sampling stations of Dhamra Estuary

\section{REFERENCES}

Botes, L, Phytoplankton Identification Catalogue. Saldanha Bay, South Africa, April 2001. (GloBallast Monograph Series No. 7. IMO London).

Cleorn, J N (1987). Turbidity as a control on phytoplankton biomass and productivity in esturies. Continental Shelf Research, 7: 13671387.

Dawes, C J (1981). Marine Botany, A WileyInterscience publication, USA.
Ferreira, J G ; Wolff, W J; Simas, T C ; Bricker, S B (2005). Does biodiversity of estuarine phytoplankton depend on hydrology?, Ecological Modeling, 187: 513-523.

Gao,X ; Song,J (2005). Phytoplankton distributions and their relationship with the environment in the Changjiang Estuary, China. Marine Pollution Bulletin, 50: $327-$ 335. 
Gilbert, J Y (1942). 'The errors of the SedgwickRafter counting chamber on the enumeration of phytoplankton', Transactions of the American Microscopy Society, 61 : 217-226.

Grasshoff, K ; Kremling, K ; Ehrhardt, M (1999). Methods of Seawater Analysis, Wiley-VCH, Weinheim .

Hergenrader, Gary L (1980). Eutrophication of the salt valley reservoirs, 1968-1973 II. Changes in physical and chemical parameters of eutrophication, Hydrobiologia, 74(3): 225240.

Kinne, 0 (ED) (1972). Marine ecology.Vol 1. Environmental factors. Part 2,Wiley Interscience, London.

Lionard, M ; Muylaert, $\mathrm{K}$; Gansbeke, D V ; Vyverman,W (2005). Influence of changes in salinity and light intensity on growth of phytoplankton communities from the Schelde River and estuary (Belgium/The Netherlands), Hydrobiologia, 540: 105-115.

Madhu, N V ; Jyothibabu, R ; Balachandran, K K ; Honey, U K ; Martin, G D; Vijay, J G ; Shiyas, C A; Gupta, G V M; Achuthankutty, C T (2007). Monsoonal impact on planktonic standing stock and abundance in a tropical estuary (Cochin backwaters- India), Estuarine, Coastal and Shelf Science, 73: 5464.
Madhupratap, $\mathrm{M}$; Gauns, $\mathrm{M}$; Ramaiah, N ; Prasanna Kumar, S ; Muraleedharan,P M; de Sousa, S N ; Sardessai, S ; Muraleedharan ,U (2003). Biogeochemistry of the Bay of Bengal: physical, chemical and primary productivity characteristics of the central and western Bay of Bengal during summer monsoon 2001, Deep Sea Research Part II: Topical Studies in Oceanography, 50 (5): 881-896.

OXNER, M (1920). Chloruration par a Méthode de Knudsen, Bull. Comm. Int. Explor. Mer Méditerranée, 3: 36 .

Shannon, C E ; Weaver, W (1949). The mathematical theory of communication, (The University of Illinois Press, Urbana), 117.

Steinhart,G S ; Likens,G E ; Soto,D (2002). Physiological indicators of nutrient deficiency in phytoplankton in southern Chilean lakes, Hydrobiologia, 489(1-3): 2127.

Verlencar, X N ; Desai ,S (2004). Phytoplankton Identification Manual, First Edition : March 2004, National Institute of Oceanography ,Dona Paula, Goa ,India. 